\title{
ЛюДИНОТВОРЧА СУТНІСТЬ КУЛЬТУРИ У ФІЛОСОФІї В.І. ШИНКАРУКА
}

\begin{abstract}
O.О. Фаріон
Розробка філософських проблем культури, зокрема культурних основ діяльності та вільного розвитку особистості, завжди залишаеться актуальною, адже наше бачення світу значною мірою дається нам саме у соціокультурному горизонті. Зазначимо, що при аналізі проблеми культури важливо розрізняти буденне і філософське (теоретичне) її бачення. Буденне уявлення поняття «культура» включає літературу, мистецтво, морально-естетичне виховання. Часто сюди додають сферу освіти і виховання підростаючого покоління. Суспільні науки (історія, археологія, етнографія та інші) вкладають у поняття культури характеристики, притаманні аналізованим ними предметам соціуму, мові, етносу, а також те, що відрізняе їх за рівнями розвитку або якісного стану. Філософський підхід до дослідження культури враховуе результати вивчення даного феномена конкретними науками, але опосередковується специфікою філософії як особливої форми світогляду і полягає в осмисленні дійсності через визначення узагальнених поглядів на світ, місце та ролі людини в ньому, через пізнання «найбільш загальних законів розвитку природи, суспільства і людського мислення». Тож у такому вимірі феномен культури не може бути зведений до одного чи декількох природних або соціальних утворень. Філософія охоплюе світ в цілому в його відношенні до людини, останній і е світом людської культури. Крізь призму філософії культура постає в узагальнених характеристиках як форма, результат, спосіб зв'язку людини 3 дійсністю, утвердження людини, як прояв і утвердження сутнісних сил людства [6, с. 178$]$.

В українській філософській думці досить глибоко укорінена тради-
\end{abstract}

Актуальні проблеми духовності

(Відп. ред.: Я.В. Шрамко)

Кривий Pir (2008), 236-245 
ція висвітлення людинотворчої сутності культури. Не в останню чергу ця традиція пов'язана 3 творчістю видатного українського філософа Володимира Іларіоновича Шинкарука, який у 70-ті роки ХX ст. усебічно обгрунтував необхідність визначення соціальної ефективності суспільної життедіяльності не за кількісними, а за якісними показниками, передусім-ступенем розвитку людини, її здібностей, можливостей, світоглядних орієнтирів. Він висунув важливу в теоретикоантропологічному й практичному відношеннях тезу про те, що взаємодія продуктивних сил та виробничих відносин небачено загострює питання про креативний потенціал суб'єктів виробничої діяльності, вимагав високої інтелектуальної й загальносвітоглядної культури, яка б забезпечила достатню цілесмислову регуляцію усіх сфер людської діяльності.

У такий спосіб B.I. ШІинкарук ініціював філософське осмислення суспільно-культурних явищ, наголосивши на тому, що критерієм ефективності певного типу суспільства $є$ його людиностимулюючі потенції. 3'ясування суперечливості людської діяльності вивело його на вивчення людиноформуючих функцій культури.

Перш за все, слід розглянути два можливі шляхи розробки та висвітлення поняття культури, які окреслив В.І. Шинкарук:

1) критичний аналіз та узагальнення наявних у культурологічній та філософській літературі визначень цього поняття;

2) розгляд і теоретичний аналіз генезису цього поняття в історії думки (історична самосвідомость культури).

Як вважав B.I. Шинкарук, перший шлях приводить у кращому разі до більш чи менш вдалих «уточнень», «конкретизацій» та доповнень наявних уже в літературі дефініцій. Другий - до висвітлення об'єктивного змісту поняття, історичного формування його змісту в самій культурі. Більш плідним є саме останній шлях (див. [8]).

Історичне становлення культури здійснювалось у процесі соціоантропогенезу. Культура творилась людиною та творила людину, бо в ній і через неї формувався «надприродний», суто людський спосіб буття у світі. Людське буття принципово відрізняеться від тваринного як природно-надприродне, самодетерміноване, вільне. Міра цієї свободи визначається мірою розвитку надприродного, культурного світу. Мова, міф, мистецтво і релігія - складові символічного світу, що у своїй сукупності створюють певне середовище - призму, через яку людина 
сприймае фізичну реальність. Тому розвиток людської думки та досвіду визначає сприйняття навколишнього світу.

Аналізуючи культуру, як систему форммтворень людського духу, B.I. Шинкарук виокремив такі основні культурні форми, в яких і через які здійснюється становлення та розвиток людського духу: мова, гра, міф, казка, праця, людські прихильності, наукові (зокрема історичні) знання.

Мову мислитель визначив як «орган культури», безпосередне буття культури, що його творить кожна нація, становлячись напіею як такою. Людинотворчий, буттійний статус мови глибоко висвітлено в працях М. Хайдеггера та у філософській герменевтиці Х.-Г. Гадамера. «Дар мови, - пише Хайдеггер, - вирізняе людину, лише й роблячи іï людиною. Цією рисою окреслено її єство. Людина не була б людиною, коли б їй було відмовлено в тому, щоб мовити - безперервно, всеосяжно про все, в багатоманітних різновидах і в більшій частині у невимовленому - «це $\epsilon$ те». Оскільки все це і подібне забезпечує мова, сутність людини міститься в мові» $[4$, с. 259$]$.

Оволодіваючи мовою та розмовляючи між собою і з собою, люди відкривають для себе світ свого людського буття. Таким чином, як зауважував В.І. Шинкарук, у мові «мовлять про себе» всі речі, що входять у світ людського буття. Мова відкривае «потаємну» суть речей. Про це говорить саме слово «річ» у вислові «у чому річ?». Те саме в російській мові: «вещи вещают», «ве-щать», «извещать» (див. [8]). У мові і через мову світ постає перед людиною, «відкривається» їй у своїх людських значеннях. Через це Хайдеггер визначив мову як «дім людського буття», відзначивши, що «мова ніколи не $є$ просто вираження думки, почуття й бажкання. Мова - той вихідний вимір, у середині якого людська істота загалом вперше і є здатною відгукнутися на буття та його поклик і через цю здатність належати до буття. Цією вихідною чуйністю, істинним чином досягненою, є думка. Думаючи, ми вперше вчимося мешкати в тій обителі, де реалізуеться доля нашого буття» [4, c. 254-255].

Як один 3 найперших феноменів культури в історичному та в індивідуальному становленні людини й людства В.І. Шинкарук розглядав еру. Гра виникає на основі духовних потенцій людини, реалізуе їх, розвивае, підносить до найвищих сягань людського духу; їй властиві порядок, напруження, динаміка, урочистість, захопленість. Таким чином, гра є саме формотворенням людського духу, причому одним 3 первісних «започатковуючих».

Також первинними соціокультурними формами становлення і роз- 
витку людського духу в історичному плані е міфи, в індивідуальному - казки. У міфах домінуе чуттево-ціннісне сприйняття світу, переживання його як драми розгортання подій, сповнених людських смислів і людських призначень. Казки ж-не просто дитячі забавки, а історично вироблені культурні форми становлення й розвитку людської свідомості. Уявне, створене фантазією та виражене символічною казковою мовою, переживається і засвоюеться як дійсне. Таким чином, боротьба персоніфікованих сил добра й зла, правди й кривди, любові й відрази та ін. формують основи людської моралі (див. [8]).

Важливоюо передумовою духовного розвитку людини $є$ праця. В.І.Шинкарук підкреслював визначальність суспільної праці в суто людській життєдіяльності, так як вона формує насамперед волю, здатність стримувати, переборювати свої безпосередні бажання й тваринні інстинкти, підпорядковувати свою діяльність суспільним цілям. Оскільки суспільна праця здатна практично й духовно перетворювати дійсність і саму людину, В.І. Шинкарук визначив $\dddot{1}$ як джерело культури $[3$, с. 320]. Сучасні технічні засоби, механізуючи і полегшуючи домашню працю, мінімалізують традиційні форми раннього залучення дітей до праці. У результаті-нівелювання визначального засобу формування людської волі. Щоб стати творцем, людина за будьяких соціальних умов мае пройти школу праці, оволодіти майстерністю, засвоїти історично вироблені «стандарти» людської діяльності. Формування людської волі неможливе без самопримусу, без дисципліни праці.

Обгрунтувавши працю як розумну діяльність, у якій і через яку виявляється сутність людського в людині, В.І. Шинкарук поставив останню у центр процесу діяльності, значно глибшого, ніж ті, які фіксуються поняттями «праця», «виробництво» і навіть «практика». Адже поняття «діяльність» охоплюе найістотніше в людині- їі свободу як «здатність робити власний вільний вибір серед різних і альтернативних можливостей, що містяться в обставинах діяльності,- лише тих, які відповідають її потребам i, реалізуючи їх, створювати свій людський світ, оновлювати і збагачувати його предметами й цінностями, безпосередньо не даними в природі-культурою» $[8$, с. 54].

Визначальними факторами становлення людської особистості $\epsilon$ також формування людських прихильностей (любові до рідних, відданості їм та ін.) і громадських почуттів, яке здійснюеться через:

- виникнення почуття й свідомості свого людського та громадянського обов'язку, вироблення здатності підпорядковувати свою 
діяльність інтересам та цілям суспільства, усвідомлення громадських інтересів як вищих, ніж особисті;

- формування особистої індивідуальності, особистих уподобань, схильностей і характеру, вироблення почуття особистої гідності, усвідомлення своєї самоцінності як людини серед людей.

У цих двох параметрах - громадському й особистому - формуються людські почуття, як, зрештою, і сама людська особистість. Величність і краса людини не лише в її розумі, а й у її людських почуттях, у $\dddot{̈}$ людяному «гарячому» серці, і вони не дані їй «від народження», а є продуктом виховання, здобутком засвоєння людської культури.

Винятково важливу роль у формуванні й розвитку людських почуттів відіграють художня література, мистецтво. У своему предметному бутті-у творах, що споглядаються та сприймаються, - культура $є$ формами руху людського почуття, його глибини та сили, емоційного змісту. Через мистецтво людина переживае уявне як дійсне, минуле і майбутне як сучасне, входить у світ інших людей, а саме: живе їх життям, вводить у свій світ світ усього людства.

Наукові, зокрема історичні знання формують національну свідомість, усвідомлення людиною своєї причетності до певного народу, нації, людства загалом. Сутність та зміст культури В.І. Шинкарук розглядав через призму історії, враховуючи всезагальні закони розвитку. Він стверджував, що культура історично та логічно виникає як система засобів виживання людини та як сфера становлення людської сутності. Її елементи та сфери формуються у зв'язку з об'єктивною необхідністю для людини вижити у боротьбі з природою, і тут культура виступає (і у своїй виробничій функції, і у функції організації, регулювання суспільних відносин) як засіб. Однак у подальшому розвитку зміст засобу все більшою мірою набувае неутилітарного, духовного, ціннісного, смисло- та життетворчого характеру. Культура стає сферою самореалізації, саморозвитку, самосвідомості людини. Більше того, вона перетворюеться у сферу виявлення творчих можливостей людини, вона стає виміром $\dddot{1}$ самооцінки. Культура охоплюе визнані тою чи іншою групою цінності. Оцінка особистістю своєї поведінки, відповідно до даних цінностей, стає важливим засобом задоволення потреби людини у смислі життя [6, с. 179-180].

Отже, В.І. Шинкарук визначив культуру, перш за все, як історично вироблені способи суспільно-цільової діяльності людей та продукти пієї діяльності, що мають позитивно-ціннісне значення для суспільного 
прогресивно-гуманістичного розвитку. Кожен індивід стае людиною тією мірою, якою він засвоїть людські способи діяльності: навчиться діяти з предметами по-людськи, по-людськи говорити, по-людськи мислити. Для того, щоб діяти відповідно до своєї мети, люди повинні пізнати свої якості та закони об'єктивного світу, узгодити з ними свою діяльність.

Людина стверджуе себе у світі всіма своїми почуттями. Духовні почуття людини, і перш за все моральні, виступають визначальним суб'єктивним фактором переживання створюваного свідомістю світу майбутнього - світу віри, мрії та надії-як світу реалізації цих почуттів. Питання про сутність цього світу та його відношення до предметного світу сучасного і минулого, за B.I. IIинкаруком є основним питанням світоzляду [5, с. 66].

Світогляд мислитель визначив як форму суспільної самосвідомості людини (індивідів, соціальних груп, класів, суспільства), через яку суб'єкт світогляду сприймає, осмислюе та оцінюе навколишню дійсність як світ свого буття й діяльності, визначае та переживае свое місце, призначення $\mathrm{i}$ «долю» в ньому. Формуючись разом зі свідомістю на основі практики суспільного життя, світогляд реалізуе потреби та цілі практичного перетворення світу духовно, виступаючи як його практично-духовне освоєння [3, с.608]. Поряд із відповідними світоглядними знаннями, принципами й ідеалами світогляд базуеться на цілій низці духовних феноменів, що входять до всіх історичних форм культури. Отже, світогляд і духовна культура перебувають у глибокій органічній едності, одне без одного неможливі. Визначальним у духовному змісті культури е світогляд, що реалізуеться в тріаді: світорозуміння, світосприймання і світовідчуття.

Процес та результат об'єктивації особистісної основи людини задля досягнення внутрішньо-духовної комунікації за В.І. Шинкаруком $\boldsymbol{e}$ екзистенційно-антропологічними підвалинами культури. У цьому контексті культура постае як символічно-комунікативне оформлення особистості у стихії часу. При цьому вона може бути прив'язана до свого часу, а може виходити за його межі, у той екзистенційно-антропологічний простір, що зв'язує різні часи. Такий вихід є виявом геніальності у культурі.

Культура є виміром людського буття, яке слід розуміти не просто як «буття у світі», а як діяльність щодо «облаштування» цього світу як людського. Тому важливим методологічним принципом філософського осмислення проблем культури є принцип діяльності, який у своєму абсолютному вираженні тлумачиться як принцип пояснення основи і 
першоджерела всього сущого діяльністю «Я» («трансцендентального суб'єкта», зрештою - «духа»). Цей принцип уперше ввів у філософію Й.Фіхте, згодом його детально розробляли Г.В.Ф.Гегель, К. Маркс, представники Франкфуртської школи та ін. Досить плідне застосування принципу діяльності до розробки проблем філософії культури здійснив зокрема Е. Кассірер. Якісно нове розуміння цього принципу представлене в працях співробітників Інституту філософії АН України починаючи 3 70-тих років XX ст., де воно розглядаеться як спосіб не лише матеріального, а й практично-духовного освоєння світу, освоєння його у світогляді, у знанні й вірі, у мистецтві, культурі загалом.

На наш погляд, поняття «діяльність» $є$ глибшим, ніж поняття «практика», «праця», «виробництво» тощо. Воно охоплюе найістотніше в людині - ï свободу як здатність робити власний вільний вибір серед різних і альтернативних можливостей, що містяться в обставинах діяльності, лише тих, які відповідають її потребам, i, реалізуючи їх, створювати свій людський світ, оновлювати й збагачувати його предметами й цінностями, безпосередньо не даними в природі, - культурою.

3 принципом діяльності внутрішньо пов'язаний принцип бутійності. У певному розумінні вони тотожні. Адже людина за своєю суттю є діяльна істота і самодіяльність є її власне людським буттям. Життєдіяльність людини відбувається завжди в певному просторі й часі. B.I. Шинкарук зауважував, що реально сущою $є$ наша життєдіяльність лише в теперішньому (у минулому вона вже була і тому вже не суща, а в майбутньому ще не була-ще не суща). Тож діяльність, буття й існування мають різні часові виміри.

У застосуванні до осмислення поняття культури принцип бутійності потребуе розгляду культури в трьох часових вимірах і в розрізненні буття й сущого. Минуле в культурі та минулі культури осягаються через буття у сучасній культурі, через наявну в ній історичну пам'ять, традиції. Культурні новації виводять наше сьогоденне буття в безмежжя соціокультурного простору і часу, «оберненого» 3 минулого в майбутне. Тому справжне відродження в культурі і самої культури можливе лише через її розвиток, збагачення, відкриття «нових», прийдешніх «світів» (див. [8]). Отже, як першочергове завдання сучасної культури B.I. Шинкарук визначає успадкування та розвиток прогресивних, гуманістичних традицій культури минулого, збагачення надбаннями теперішньої світової культури. Сучасна культура, збагачуючи світову культуру, обов'язково повинна виявляти себе як могутній фактор духовного прогресу людства. 
Нагальною проблемою, яка все більше загострюеться в процесі модернізапії сучасної культури $\epsilon$ взаємоврівноважування особистісного, індивідуальнісного і загального. Проблемою $є$ - так звана уявна загальність, пов'язана зі схильністю людини універсалізувати те, що універсалізувати не варто. Відповідно, людська життедіяльність заражена ілюзією свободи однієї частинки буття (людини) - за рахунок буття в цілому. Зокрема відомий український філософ світоглядноекзистенціальної спрямованості О. Кульчицький акцентував увагу на тому, «що стехнізована цивілізація заволоділа персональною надбудовою і, з одного боку, витіснила з неї культуротворчі цінності, а з іншого, ,затиснула“ ендотимне підпілля, наявне у кожного $з$ нас, перервала природно-життевий зв'язок людини з первинною природою, без якої неможливе його виживання» (див. [2, с. 32-33]). Занепад же ендотимних підвалин рівнозначний висиханню джерел світоглядно-психічної стійкості, а це, в свою чергу, провокуе численні світоглядно-психічні колізії сучасної людини, у тому числі в когнітивній сфері.

Оскільки досягнення культури доступні широким верствам населення, важливо, щоб культура виконувала інформаційно-просвітницьку функцію, формувала в людині особистість, надихала на високі почуття та прагнення, а не знецінювалася, не втрачала свою унікальність та достеменність. Всебічний процес масовізації культури не повинен супроводжуватися зниженням їі інтелектуального, естетичного, морального рівня, вести до нівелювання її високої гуманістичної місії.

В.І. Шинкарук грунтовно вивчав людиноформуючі функції культури з метою створення дієвої системи заходів боротьби з вищевказаними негативними тенденціями, які, на жаль, суттево поширені у сучасному суспільстві. 3 цією ж метою у поняття культури філософ рекомендував ввести аксіологічний підхід, бо вбачав необхідність у розмежуванні істинно культурного та технологічного. Адже антигуманні, руйнівні дії можуть здійснюватися згідно останнього слова науки і техніки. Культура ж за своєю сутністю має бути гуманістичною, являти собою сферу та спосіб самоствердження, саморозвитку, возвеличення людини. Саме культура повинна стояти на сторожі цінностей, особливо таких, що мають не лише утилітарну, технологічну, а й найвищу - гуманістичну цілевідповідність [6, с. 195].

Ціннісні відношення виникають у практичній життедіяльності людей $\mathrm{i}$ детермінуються їх первинними біологічними та соціально-економічними потребами. Але відповідно до процесів практичного формування культурного субстрату для людини все більшої вагомості набуває самосвідомість, самоствердження, життя зі змістом. Тож закономірно 
над первинно-утилітарними, технологічними пінностями створюеться і міцніє якісно нова надбудова - цінності найвищого рівня. Останні $е$ певною мірою автономними і формуються у відносно самостійний розвиток культури.

Цінності культури неможливо однозначно вивести з сучасного, на даний момент функціонуючого буття, 3 даних конкретних способів практики. Вони - квінтесенція, наслідок історичного досвіду людства. Цінності добра, краси, справедливості, свободи не просто сформовані, а вистраждані людством протягом усієї історії. I як такі вони возвеличуються над практикою, незалежні від неї, самі активно впливають на формування її цілей, мотивів, на вибір основних стимулів до діяльності. Коли йдеться про детермінуючу дію вказаних цінностей, цілком байдуже, реальні чи нереальні вони за своїм об'ективним змістом. У даному випадку вирішальне значення має те, сприйняті чи відкинуті вони суб'єктом, якому адресовані.

Таким чином, виховання особистості передбачає перш за все формування її ціннісної свідомості. Чим більше поле культури засвоїв індивід, чим глибше та якісніше він це зробив, тим більшою мірою сформовані у його свідомості цінності відповідають сутності людини і потребам прогресивного розвитку суспільства. У свою чергу світ буття людини виступае як культура лише в тому разі, коли він здійснюе функцію «формотворення людського духу», тобто формування людини. Ідеалом цілісності та гармонійності за В.І. Шинкаруком є людина, всі сфери духу якої - почуття, воля, розум - перебувають у такій мірі взаемодії, де почуття формуеться на основі розуму, а розум «осяяний горінням» почуття, де воля являє собою едність діяльності почуття та розуму, що скеровані на свою предметну реалізацію. Засобом формування та розвитку духовності він визначав культуру в усіх їі формах і вимірах: мистецтві, науці, філософії, релігіі, моральній та правовій свідомості, святах та обрядах, у загальнолюдському і національному в усьому, що формуе мудрість, любов, віру, надію, справді людське в людині.

\section{1 Бібліографія}

[1] Козловець M.A. Сучасна культурна глобалізація й національна ідентичність // Вісник Черкаського університету. - Вип. 109. Серія Філософія. - Черкаси, 2007. - С. 5-13. 
[2] Табачковський В.Г. Життевий світ людини і пізнання: персоналістична інтерпретація // Філософська думка. - 2006. - № 2. C. $14-34$.

[3] Філософський словник. За ред. В.І. Шинкарука. - К.: Головна редакція УРЕ, 1986.

[4] Хайдеггер M. Время и бытие.--М., 1993.

[5] ПІинкарук В. Философия и мировоззрение // Общественные науки. $-1979 .-$ № 5 . - С. $61-74$.

[6] Шинкарук В.И., Яценко А.И. Гуманизм диалектикоматериалистического мировоззрения. - К.: Политиздат Украины, 1984.

[7] Шинкарук B.I. Духовная культура - человек - искусство // Шинкарук В.I. Вибрані твори: у 3-х т. - К.: Український Центр духовної культури, 2004. (Філософська спадщина України). - Т. III. Ч. I. - C. $297-310$.

[8] Шинкарук B.I. Поняття культури. Філософські аспекти // Андрос $Є$. ., Арестова Н., Бистрицький $Є$. та ін. Феномен української культури: методологічні засади осмислення. - К.: Фенікс, 1996.C. $8-61$.

[9] Шинкарук B.I. Світогляд і духовна культура: (Питання історичного генезису) // Філософська думка. - № 2. - С. 27-37. 